\title{
OPTIMASI PENGGUNAAN SEDIMENT TRAP PADA ALUR PELAYARAN BARAT SURABAYA MENGGUNAKAN PEMODELAN TRANSPOR SEDIMEN (STUDI KASUS: ALUR PELAYARAN BARAT SURABAYA, JAWA TIMUR)
}

\author{
Danar Guruh Pratomo1, Muhammad Rinaldi Fauzan Aziz² \\ 1,2Institut Teknologi Sepuluh Nopember; Jl. Raya ITS, Keputih, Kec. Sukolilo, Kota SBY, Jawa Timur 60111 \\ Departemen Teknik Geomatika, FTSLK-ITS, Kampus ITS Sukolilo, Surabaya, 60111, Indonesia \\ e-mail: ${ }^{1}$ guruh@geodesy.its.ac.id, ${ }^{2}$ mrfaziz255@gmail.com
}

\begin{abstract}
Abstrak
Pelabuhan Tanjung Perak merupakan salah satu pelabuhan terbesar di Indonesia yang cukup strategis bagi perkembangan ekonomi dan transportasi laut. Diperlukannya penanganan bagi alur pelayaran agar lalu lintas kapal tetap stabil. Lokasi penelitian di Alur Pelayaran Barat Surabaya dengan 3 kondisi berbeda yaitu Pre-Survey, Post-Survey kondisi 1 memiliki sediment trap dan Post-Survey kondisi 2 tidak memiliki sediment trap. Penelitian menggunakan pemodelan 3D untuk melihat aktifitas hidrodinamika. Hasil dari pemodelan adalah pola arus, yang akan mempengaruhi pola sebaran sedimen pada area penelitian. Model dibentuk berdasarkan parameter berupa pasang surut, debit sungai, dan angin di daerah penelitian. Pasang surut Pre-Survey memiliki nilai RMSE dan MAE sebesar 0,0307 meter dan 0,0244 meter dengan arus $0,3 \mathrm{~m} / \mathrm{s}$. Post-Survey kondisi 1 memiliki nilai sebesar 0,0336 meter dan 0,0276 meter dengan arus $0,2 \mathrm{~m} / \mathrm{s}$. Post-Survey kondisi 2 memiliki nilai sebesar 0,0563 meter dan 0,0289 meter dengan arus $0,4 \mathrm{~m} / \mathrm{s}$. Pola sebaran sedimen antara Post-Survey kondisi 1 dan kondisi 2 memiliki nilai yang dominan hampir sama dimulai dari -0,005 meter hingga 0,0175 meter. Nilai maksimal kondisi 1 senilai 0,072 meter sedangkan kondisi 2 senilai 0,062 meter pada area sediment trap. Walaupun kondisi 1 memiliki nilai maksimal lebih besar dari kondisi 2, hal tersebut terjadi di beberapa titik saja.
\end{abstract}

Kata kunci : Alur Pelayaran, Arus, Pemodelan Hidrodinamika, Sediment Trap.

\begin{abstract}
Tanjung Perak Port is one of the largest ports in Indonesia that is quite strategic for economic development and sea transportation. The handling of shipping lanes is needed so that ship traffic remains stable. The research location in Alur Pelayaran Barat Surabaya with 3 different conditions namely Pre-Survey, Post-Survey condition 1 has a sediment trap and Post-Survey condition 2 has no sediment trap. Research uses 3D modeling to see hydrodynamic activity. The results of modeling are current patterns, which will influence the pattern of sediment distribution in the study area. The model is formed based on the parameters of tides, river discharge, and wind in the study area. Tidal Pre-Survey has a value of RMSE and MAE of 0.0307 meters and 0.0244 meters with a current of $0.3 \mathrm{~m} / \mathrm{s}$. Post-Survey condition 1 has a value of 0.0336 meters and 0.0276 meters with a current of $0.2 \mathrm{~m} / \mathrm{s}$. Post-Survey condition 2 has a value of 0.0563 meters and 0.0289 meters with a current of $0.4 \mathrm{~m} / \mathrm{s}$. The pattern of sediment distribution between Post-Survey conditions 1 and condition 2 has the same dominant value starting from -0.005 meters to 0.0175 meters. Maximum value of condition 1 is 0.072 meters while condition 2 is 0.062 meters in sediment trap area. Even though condition 1 has a maximum value greater than condition 2 , it occurs at just a few points.
\end{abstract}

Keywords : Shipping Channel, Flow, Hydrodinamic Modeling, Sediment Trap. 


\section{PENDAHULUAN}

Pelabuhan Tanjung Perak merupakan salah satu pelabuhan terbesar di Indonesia yang merupakan pelabuhan strategis baik itu menuju atau dari wilayah timur Indonesia yang mendukung sarana dan prasarana bagi transportasi laut dan perekonomian (Anonim, 2019). Pelabuhan Tanjung Perak memiliki Alur Pelayaran Barat yang tertulis dalam aturan Keputusan Menteri Perhubungan Republik Indonesia Nomor: KPP 455 Tahun 2016 (Kementrian Perhubungan Republik Indonesia, 2016). Alur Pelayaran ini harus aman dari pendangkalan yang diakibatkan oleh sedimentasi yang terjadi di dasar laut yang dapat mengakibatkan terganggunya alur transportasi dan aktifitas pelabuhan dikarenakan ketidaksesuaian kedalaman dengan draft kapal (Kurniawan \& Pradana, 2016).

Transpor sedimen/sedimentasi adalah perpindahan material dari 1 tempat ke tempat lainnya (Wirosoedarmo, Haji, \& Kristanti, 2008) yang dipengaruhi oleh pasang surut dan arus laut. Pasang surut merupakan naik dan turunnya muka air laut dikarenakan gaya tarik benda-benda langit terutama matahari dan bulan terhadap massa air laut di bumi (Triatmodjo, 2010), sedangkan arus adalah pergerakan massa air dari satu tempat ke tempat lainnya yang disebabkan oleh beberapa faktor salah satunya adalah pergerakan pasang surut (Kramadibrata, 2002). Sirkulasi dari arus dan pasang surut dapat membawa material sedimen yang terdapat pada perairan yang akhirnya mempengaruhi topografi dasar laut (Triatmodjo, 1999). Pada penelitian ini, Alur Pelayaran Barat Surabaya membuat sediment trap pada alur kapal tersebut yang fungsinya sebagai penahan sementara yang mengumpulkan sedimen hingga pengerukan selanjutnya (IDEQ Storm Water Best Management Practices Catalog, 2005).

Untuk itu diperlukan perawatan alur pelayaran secara berkala yang dapat dilihat melalui penambahan atau berkurangnya sedimen pada dasar laut. Penelitian ini melakukan kajian dan analisis untuk melihat keefektifan dari penggunaan sediment trap tersebut dengan menggunakan simulasi pemodelan transpor sedimen. Data yang digunakan berupa data pasang surut, batimetri, arah dan kecepatan angin, dan peta area alur pelayaran.

Penelitian ini diharapkan dapat memberikan gambaran tentang pola arus pasang surut dan pola sebaran sedimen dari penambahan dan penurunan di dasar laut, sehingga dapat digunakan sebagai analisis lebih lanjut mengenai keefektifan dari penggunaan sediment trap di alur pelayaran tersebut.

\section{METODE}

\section{Data dan Peralatan}

Data yang digunakan dalam penelitian ini adalah:

1. Data batimetri pengukuran Alur Pelayaran Barat Surabaya Pre-Survey dan Post Survey tahun 2018

2. Data pasang surut pengukuran.

3. Data pasang surut Real-Time

4. Data kecepatan dan arah angin tahun 2018

5. Data debit sungai

6. Peta RBI Jawa Timur, dan Peta Laut Indonesia daerah Alur Pelayaran Barat Surabaya. ini adalah:

Peralatan yang digunakan dalam penelitian

1. Perangkat lunak pengolah pasang surut

2. Perangkat lunak pengolah batimetri

3. ArcGIS 10.6.1

4. Perangkat lunak pemodelan

\section{Metode Penelitian}

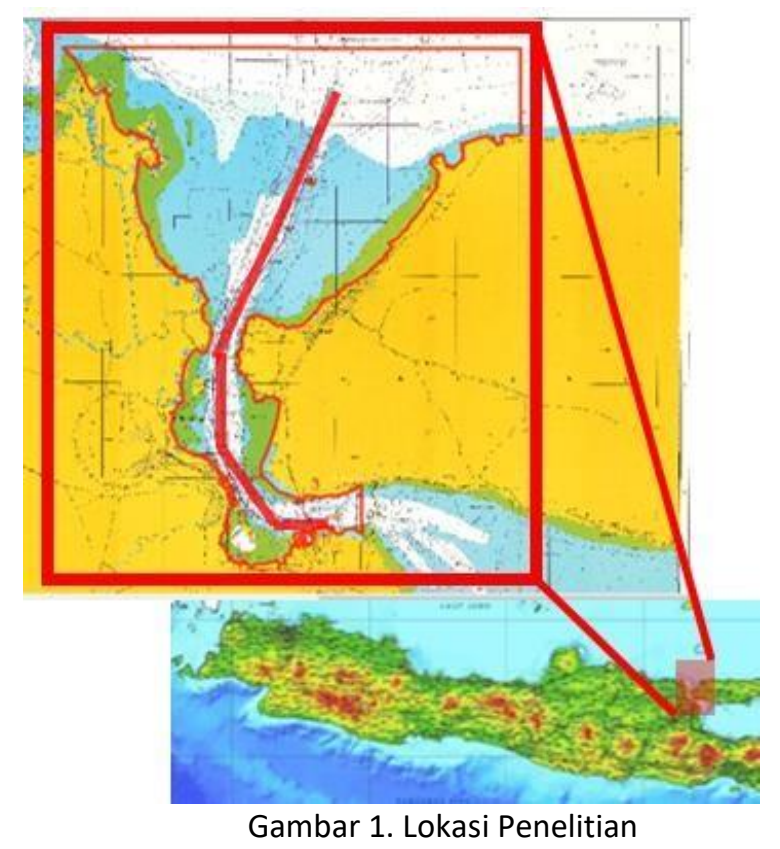

Penelitian ini dilakukan di area Alur Pelayaran 
Barat Surabaya sesuai dengan koordinat yang berada pada Keputusan Menteri Perhubungan Republik Indonesia Nomor: KPP 455 Tahun 2016. Lokasi penelitian ditunjukan pada Gambar 1.

$$
\text { Pemodelan dilakukan dengan }
$$
menggunakan metode simulasi numerik dengan parameter pasang surut dan angin. Formula yang digunakan dalam melakkan pemodelan arus pasang surut adalah persamaan kontinuitas dan hukum kekekalan momentum. Diagram alir pengolahan data dalam pemodelan akan ditunjukan pada Gambar 2.

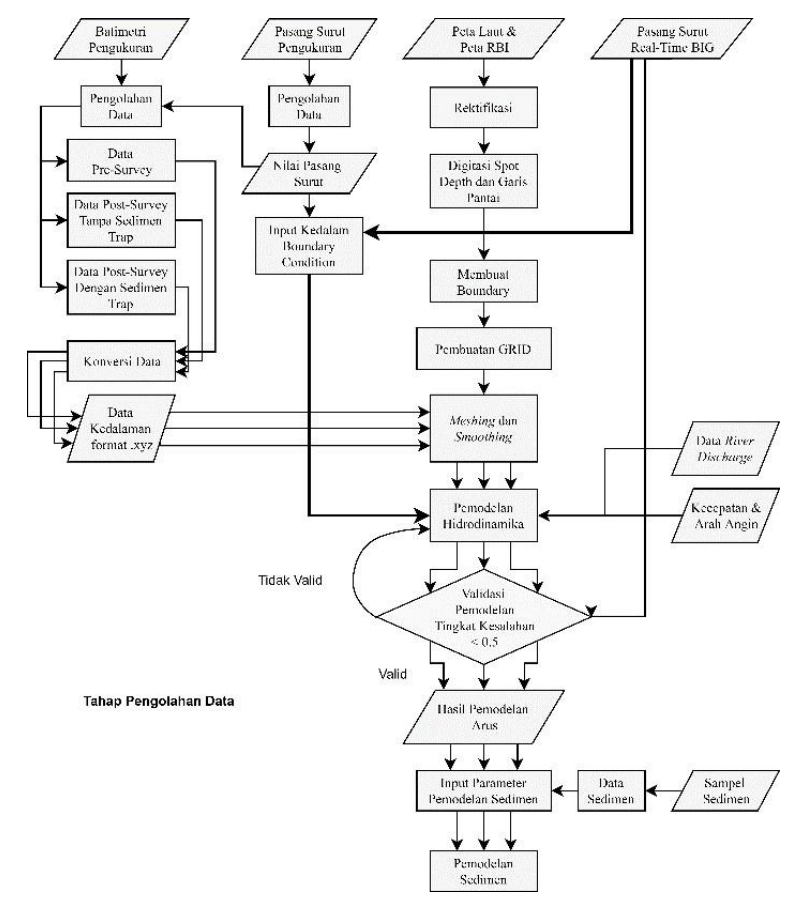

Gambar 2. Diagram Pengolahan Data

Tahapan pengolahan data berdasarkan Gambar 2 adalah sebagai berikut:

a. Pembuatan boundary atau batas yang membedakan wilayah darat dan laut dilakukan dengan digitasi garis pantai pada Peta RBI dan Peta Laut. Data vektor hasil digitasi dikonversikan kedalam format (.xyz).

b. Data batimetri hasil pengukuran juga dikonversikan kedalam format (.xyz).

c. Data boundary dimasukan kedalam software untuk pembuatan grid dengan bentuk segitiga atau TIN. Penggunaan grid berbentuk TIN dipertimbangkan karena dapat mengikuti bentuk garis pantai dan bentuk dari alur pelayaran (Chen, Beardsley, \& Cowles, 2006). Data batimetri dimasukan kedalam grid dan dilakukan interpolasi untuk membentuk mesh.

d. Data pasang surut dan angin dibuat pada modul Time Series untuk membuat grafik pasang surut dan angin sebagai persiapan data input parameter pemodelan arus.

e. Data debit sungai dimasukan sebagai input data parameter.

f. Pola arus hasil simulasi selanjutnya dihitung RMSE dan MAE dengan membandingkan antara data hasil pemodelan dengan data Real-Time. MAE digunakan untuk mendukung RMSE karena jika RMSE memiliki error yang besar pada datanya, maka hitungan yang dihasilkan pun semakin besar (Medium Corporation, 2016).

g. Hasil pemodelan arus yang dianggap baik selanjutnya dimasukan sebagai input parameter pemodelan sedimen. Hasil simulasi berupa perubahan kenaikan dan penurunan dasar laut (bed level change).

h. Analisa dilakukan dengan membandingkan hasil pemodelan sedimen pada Post Survey kondisi 1 dan kondisi 2.

\section{HASIL DAN PEMBAHASAN}

\section{Pembuatan Bidang Model (Mesh)}

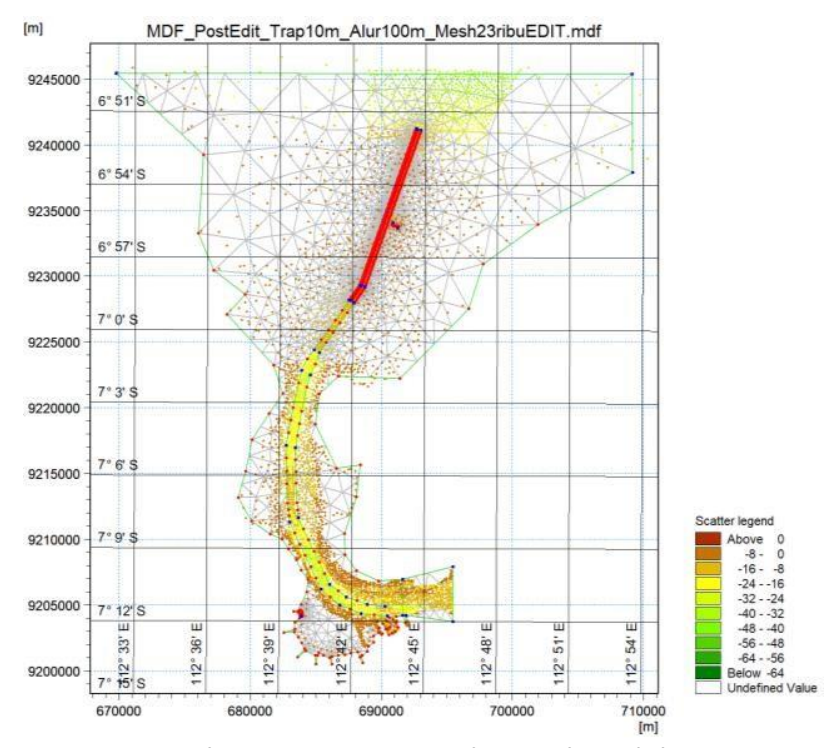

Gambar 3. Garis Batas dan Titik Kedalaman

Area meshing merupakan proses pembuatan area model kedalaman laut perairan yang dibuat menggunaakan jaring-jaring triangulasi dan interpolasi. Langkah awalnya adalah pendefinisian atribut dari masing-masing garis batas dan input data kedalaman. Garis batas 
meliputi open boundary (garis batas perairan) dan close boundary (garis batas pantai). Batas pantai didapatkan melalui digitasi peta RBI dan peta Laut. Koordinat garis batas dan titik kedalaman ditampilkan dalam sistem proyeksi UTM Zona 49S dengan referensi ellipsoid WGS84. Data kedalaman yang digunakan menggunakan referensi kedalaman MSL. Hasil pendefinisian atribut batas dan input data kedalaman ditampilkan pada Gambar 3.

Setelah itu dilakukan interpolasi kedalaman untuk mengisi data kosong sehingga menghasilkan model kedalaman laut yang ditampilkan pada Gambar 4.

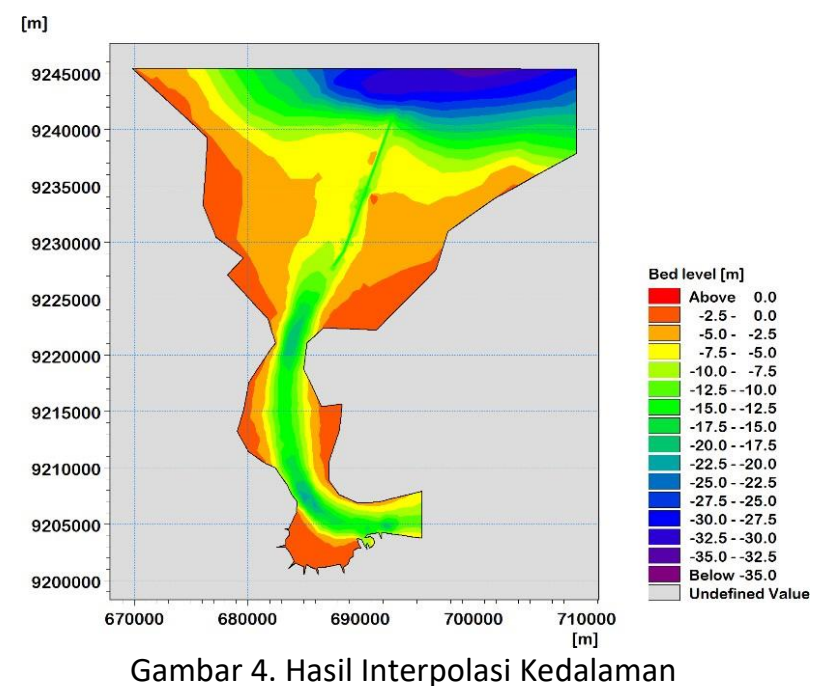

Interpolasi kedalaman dibedakan dalam warna. Semakin dalam perairan, warna yang ditunjukan mengarah ke warna ungu, dan semakin dangkal perairan, warna yang ditunjukkan ke warna merah.

\section{Pasang Surut}

Data pasang surut yang digunakan pada pemodelan adalah data Real-Time selama 40 hari baik Pre-Survey maupun Post-Survey. Dimulai pada tanggal 6 September - 15 Oktober 2018 untuk Pre-Survey dan 5 November - 14 Desember 2018 untuk Post-Survey. Gambar 5 dan Gambar 6 akan menunjukan grafik pasang surut antara data pengukuran, data Real-Time dan data hasil pemodelan.

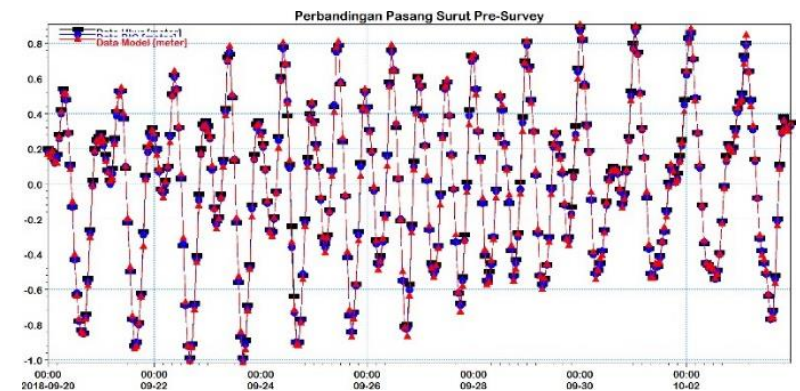

Gambar 5. Grafik Pasang Surut Pre-Survey

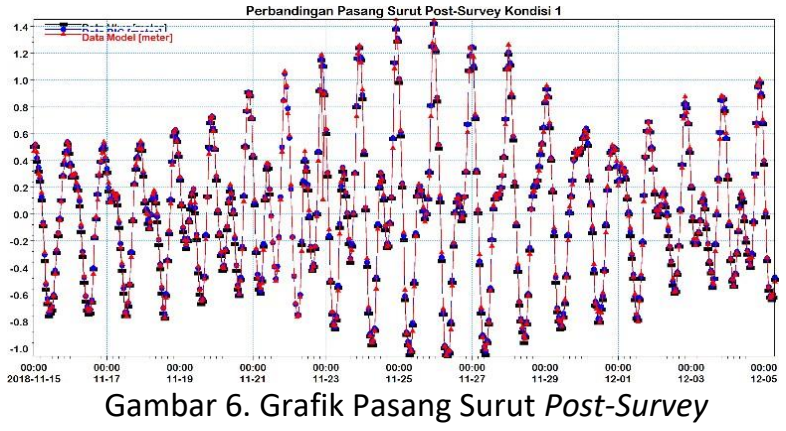

Gambar 5 menunjukan bahwa pasang surut yang dilakukan mulai tanggal 20 September 2018 hingga 3 Oktober 2018 dengan interval 1 jam memiliki nilai pasang surut tertinggi yaitu 0,9063 meter (Data Model), 0,8691 meter (Data BIG), dan 0,8899 meter (Data Ukur) hingga terendah yaitu $-1,0202$ meter (Data Model), 1,001 meter (Data BIG), dan - 0,9901 (Data Ukur).

Gambar 6 menunjukan bahwa pasang surut yang dilakukan mulai tanggal 15 November 2018 hingga 5 Desember 2018 dengan interval 1 jam memiliki nilai pasang surut tertinggi yaitu 1,4507 meter (Data Model), 1,4274 meter (Data BIG), dan 1,4182 meter (Data Ukur) hingga terendah yaitu $-1,0519$ meter (Data Model), 1,043 meter (Data BIG), dan - 1,062 (Data Ukur).

\section{Angin}

Data angin juga digunakan sebagai input parameter yang membangkitkan arus. Data didapatkan dari ECMWF dengan interval data 3 jam dimulai tanggal 1 September - 31 Oktober 2018 untuk Pre-Survey dan 1 November - 31 Desember 2018 untuk Post- Survey, yang akan ditunjukan oleh Gambar 7 dan Gambar 8. 


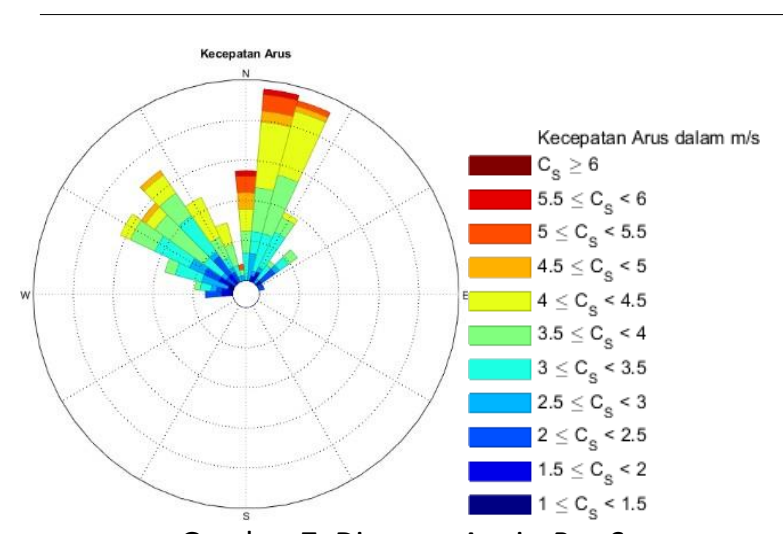

Gambar 7. Diagram Angin Pre-Survey

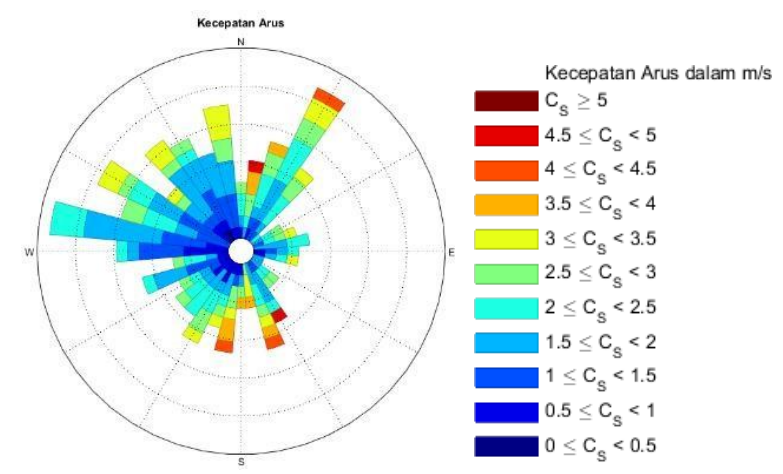

Gambar 8. Diagram Angin Post-Survey

Dari Gambar 7 dapat dilihat bahwa angin dominan mengarah ke barat laut dan utara dengan kecepatan $4,5 \mathrm{~m} / \mathrm{s}$ hingga $5,5 \mathrm{~m} / \mathrm{s}$. sedangkan Gambar 8 terlihat lebih merata pada arahnya, dengan nilai yang cukup bervariasi.

\section{Pemodelan Arus Pasang Surut}

Pemodelan arus dilakukan dengan menggunakan parameter pasang surut, angin dan debit sungai. Pemodelan dilakukan selama 40 hari dengan 5 hari awal sebagai spin up dan warming up dan interval pemodelan per 1 jam. Hasil dari pemodelan ini adalah kecepatan dan arah arus.

Validasi hasil pemodelan dilakukan untuk menentukan apakah hasil tersebut dapat dianggap baik atau tidak dengan menghitung RMSE dan MAE. RMSE merupakan penghitungan yang menyatakan perbandingan perbedaan nilai model dengan nilai observasi. Nilai MAE merepresentasikan rata - rata kesalahan (error) absolut antara hasil peramalan dengan nilai sebenarnya. Perhitungan RMSe dan MAE untuk tiap survei adalah sebagai berikut:

a. RMSE dan MAE Pre-Survey

$$
\begin{aligned}
& \text { RMSE }=\sqrt{\frac{\Sigma_{i=1}^{n}\left(y_{i}-\bar{y}_{i}\right)^{2}}{n}}=\sqrt{\frac{0,3177}{336}}=0,0307 \\
& \operatorname{MAE}=\frac{1}{\mathrm{~N}} \Sigma_{\mathrm{i}=1}^{\mathrm{n}}\left|\mathrm{x}_{\mathrm{mod}_{\mathrm{j}} \mathrm{i}}-\mathrm{x}_{\mathrm{Obbs}_{\mathrm{j}} \mathrm{i}}\right|=\frac{1}{336} 8,2057 \\
& =0,0244
\end{aligned}
$$

b. RMSE dan MAE Post-Survey kondisi 1

$$
\begin{gathered}
\text { RMSE }=\sqrt{\frac{\sum_{i=1}^{n}\left(\mathrm{v}_{i}-\overline{\mathrm{y}}_{\mathrm{i}}\right)^{2}}{n}}=\sqrt{\frac{0,2490}{220}}=0,0336 \\
\text { MAE }=\frac{1}{\mathrm{~N}} \Sigma_{\mathrm{i}=1}^{\mathrm{n}}\left|\mathrm{x}_{\bmod , \mathrm{i}}-\mathrm{x}_{\mathrm{obs}, \mathrm{i}}\right|=\frac{1}{220} 6,0618 \\
=0,0276
\end{gathered}
$$

c. RMSE dan MAE Post-Survey kondisi2

$$
\begin{gathered}
\text { RMSE }=\sqrt{\frac{\sum_{\mathrm{i}=1}^{\mathrm{n}}\left(\mathrm{V}_{\mathrm{i}}-\overline{\mathrm{y}}_{\mathrm{i}}\right)^{2}}{n}}=\sqrt{\frac{1,4845}{468}}=0,0563 \\
\mathrm{MAE}=\frac{1}{\mathrm{~N}} \Sigma_{\mathrm{i}=1}^{\mathrm{n}}\left|\mathrm{x}_{\mathrm{mod}_{\mathrm{i}} \mathrm{i}}-\mathrm{x}_{\mathrm{obs}, \mathrm{i}}\right|=\frac{1}{468} 13,5227 \\
=0,0289
\end{gathered}
$$

Dengan mengikuti klasifikasi tingkat kesalahan RMSE dan MAE dari penelitian (Khotimah, 2012), yang dijelaskan pada Tabel 1 berikut ini.

Tabel 1. Klasifikasi Tingkat Kesalahan RMSE dan MAE.

\begin{tabular}{cc} 
RMSE dan MAE & Tingkat Kesalahan \\
\cline { 1 - 1 } $0,00-0,299$ & Kecil \\
$0,30-0,599$ & Sedang \\
$0,60-0,899$ & Besar \\
$>0,9$ & Sangat Besar \\
\hline
\end{tabular}

Maka hasil dari RMSE dan MAE pemodelan, dapat disimpulkan bahwa tingkat kesalahan yang didapat masuk kedalaman tingkat kesalahan kecil, dan pemodelan dianggap baik. Menurut (Chai \& Draxler, 2014) bahwa keuntungan dari RMSE adalah tidak menggunakan nilai absolut yang biasanya tidak digunakan pada kalkulasi perhitungan. Walaupun begitu, RMSE dan MAE biasa dibutuhkan untuk menghitung kesalahan pada model.

Analisa pemodelan arus dilakukan dalam 4 kondisi yaitu (a) pasang purnama, (b) surut purnama, (c) pasang perbani dan (d) surut perbani yang akan ditunjukan oleh Gambar 9 Gambar 11, serta alur pelayaran akan ditunjukan oleh garis merah tipis. 


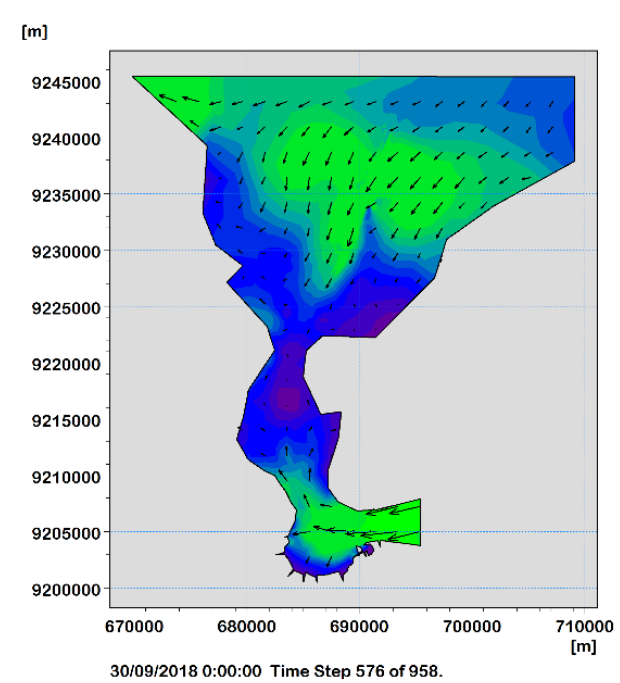

(a)

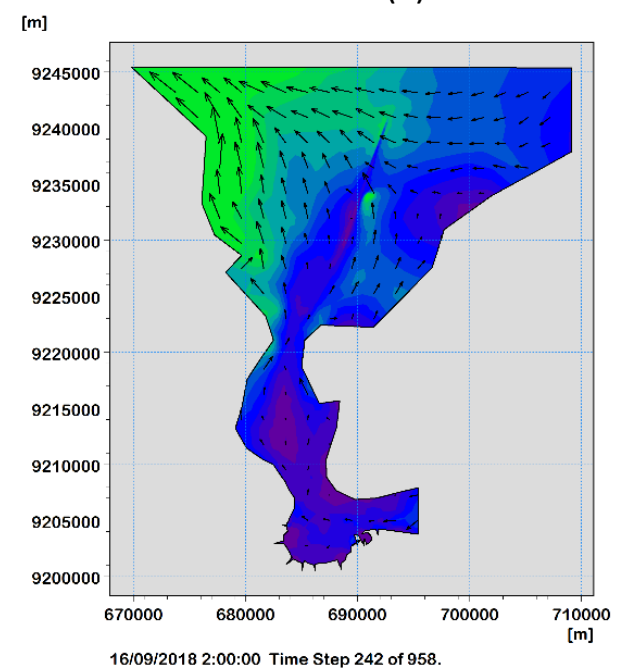

(b)

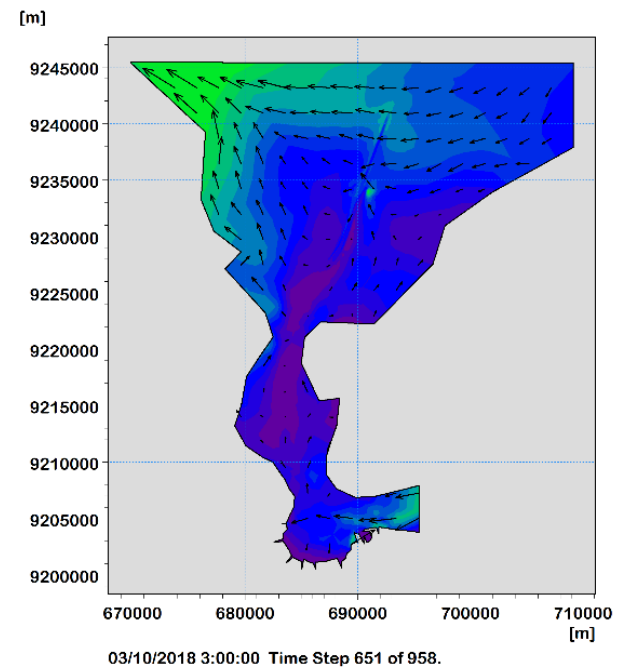

(c)

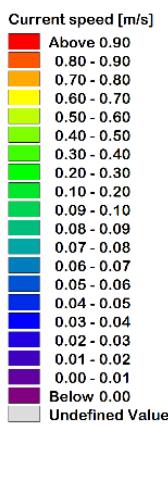
Above 0.90
$0.80-0.90$ $0.70-0.80$ $0.60-0.70$ $0.40-0.50$ $0.20-0.30$ $0.10-0.20$ $0.09 \cdot 0.10$ $0.07 \cdot 0.08$ $0.06-0.07$
$0.05-0.06$ $0.04-0.05$ $0.03-0.04$
$0.02-0.03$
$0.01-0.02$ $0.01-0.02$
$0.00-0.01$ Below 0.00 Undefined Valte
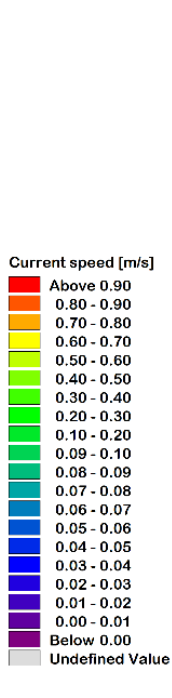

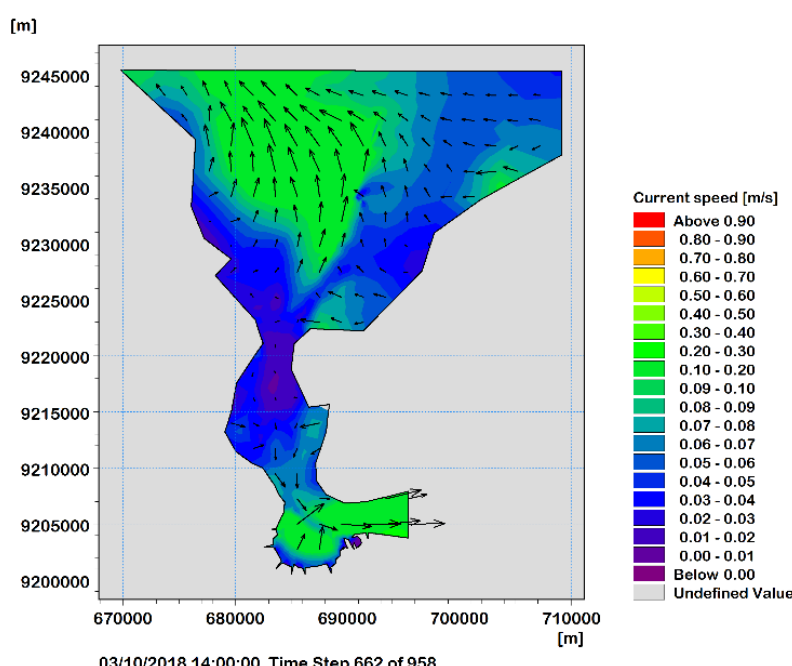

(d)

Gambar 9. Pola Arus Pre-Survey

Secara keseluruhan, arah arus yang terjadi selama pemodelan Pre-Survey mengarah ke bagian barat laut pemodelan (ditunjukan dengan lingkaran merah) dengan kecepatan maksimal terjadi pada saat pasang purnama dan surut perbani dengan nilai kisaran $0,4 \mathrm{~m} / \mathrm{s}$. Untuk wilayah dekat pelabuhan hanya saat surut perbani saja yang arah arusnya mengarah ke luar pemodelan.

Dilihat dari Gambar 10 bahwa pada saat surut purnama dan surut perbani, terjadi perputaran arus dan menuju keluar daerah pemodelan di area timur laut pemodelan yang pada kondisi lainnya, daerah tersebut cenderung memasukin area pemodelan. Kecepatan arus dominan terlihat kecil dengan nilai kisaran $0-0,05$ $\mathrm{m} / \mathrm{s}$ walaupun ada beberapa area yang memiliki nilai arus lebih besar.

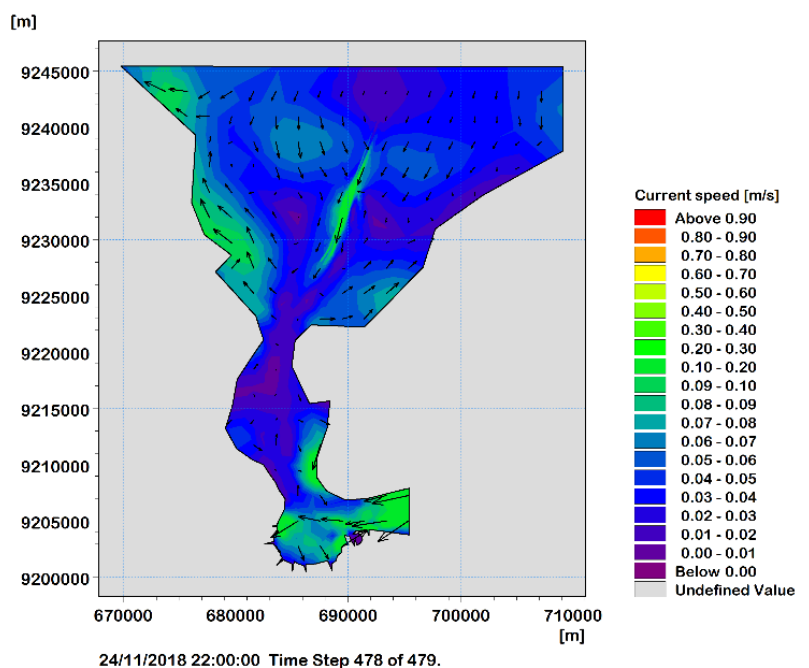

(a) 


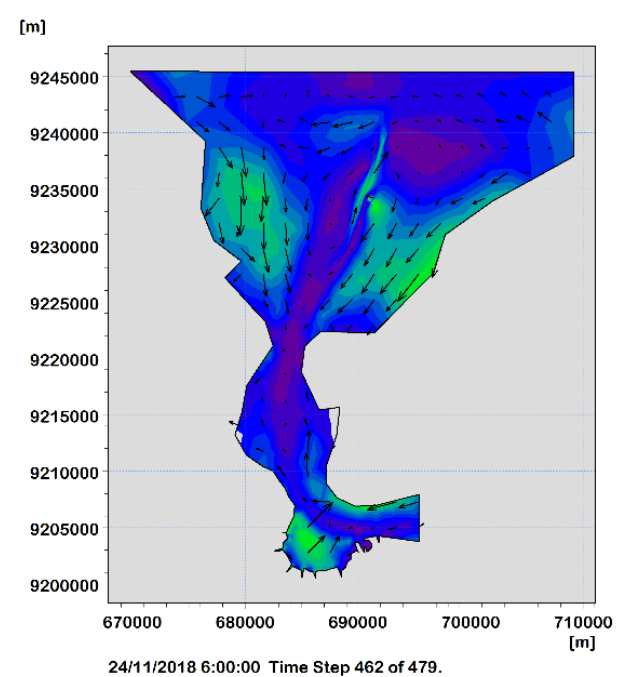

(b)

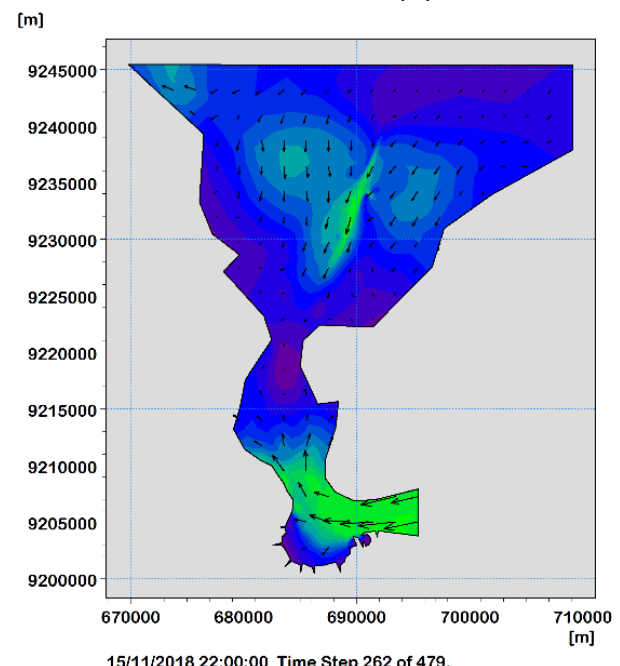

(c)

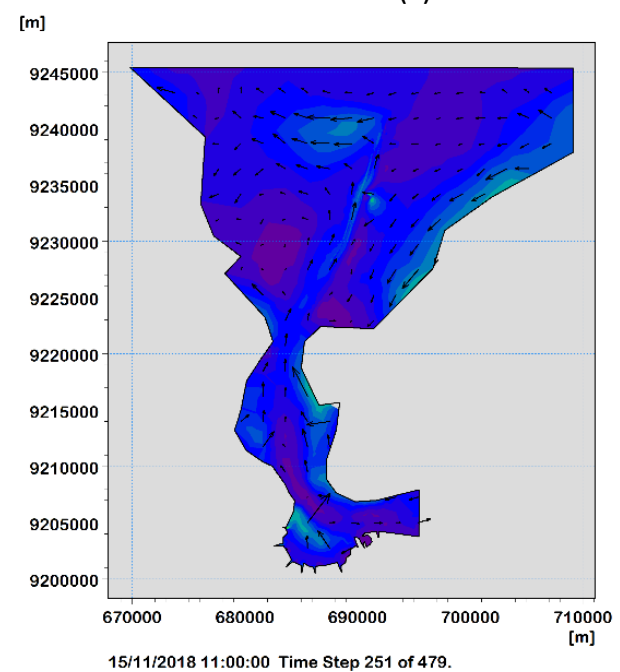

(d)

Gambar 10. Pola Arus Post-Survey Kondisi 1

Secara keseluruhan Gambar 11, terjadi perputaran arah arus di area tengah pemodelan dengan dominan arus memasuki area pemodelan. Kecepatan yang dimiliki masing-masing model 234
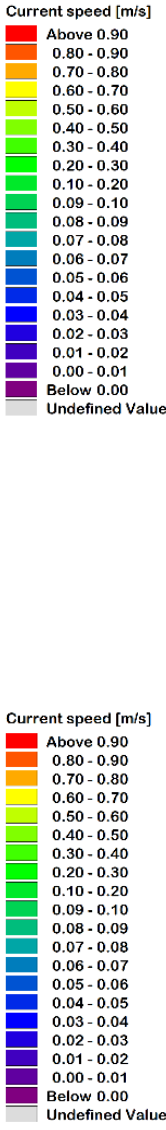

memiliki kisaran $0-0,4 \mathrm{~m} / \mathrm{s}$.

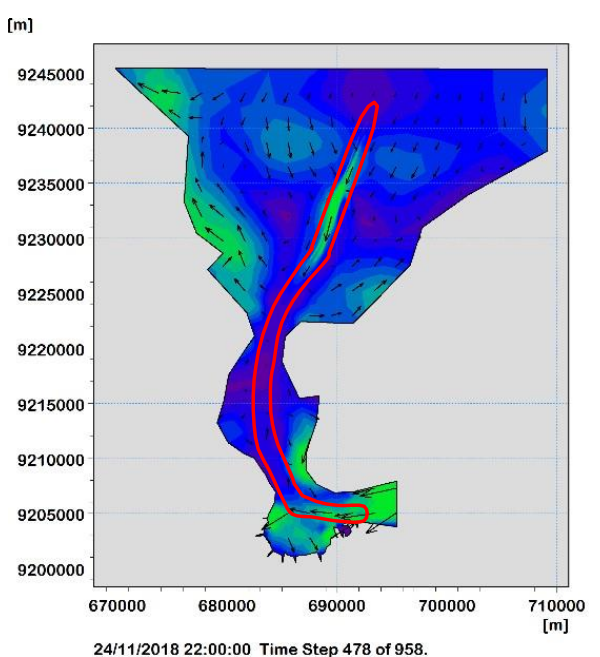

(a)
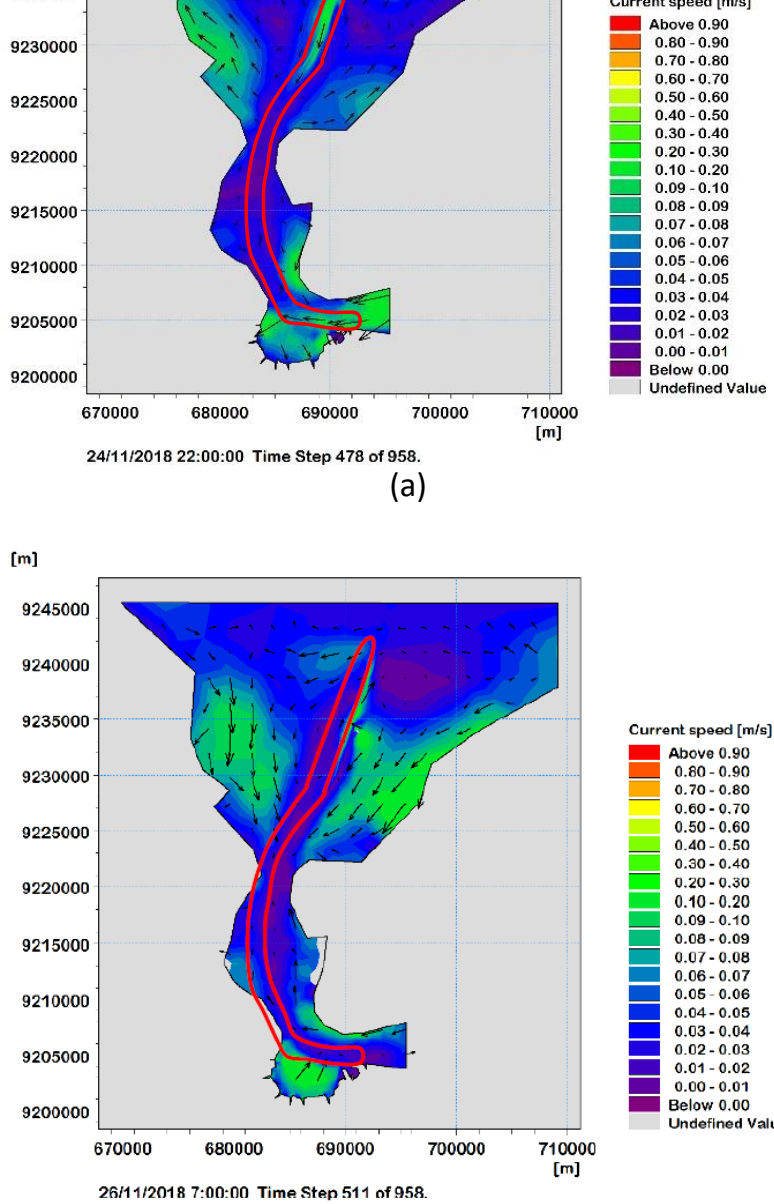

(b)

[m]
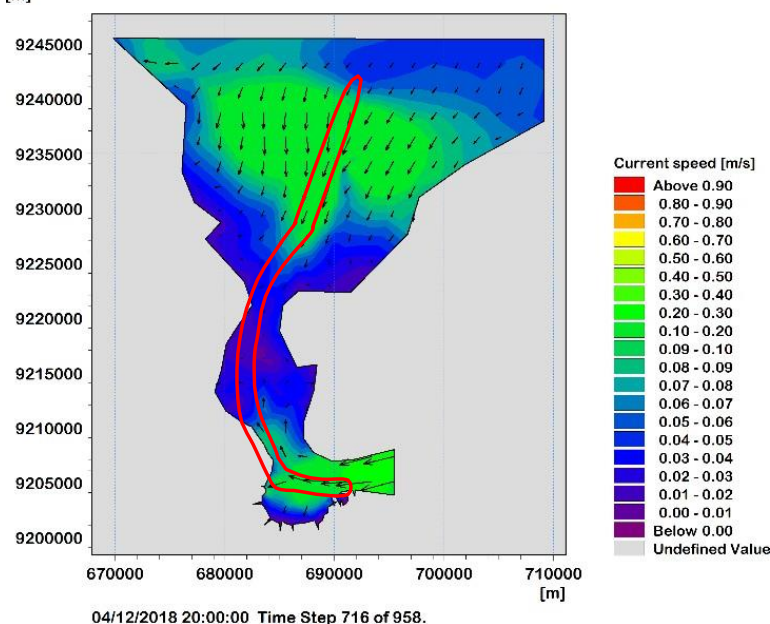

(c)

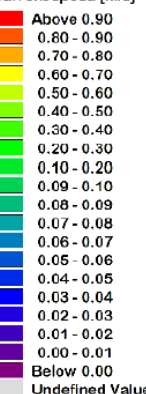




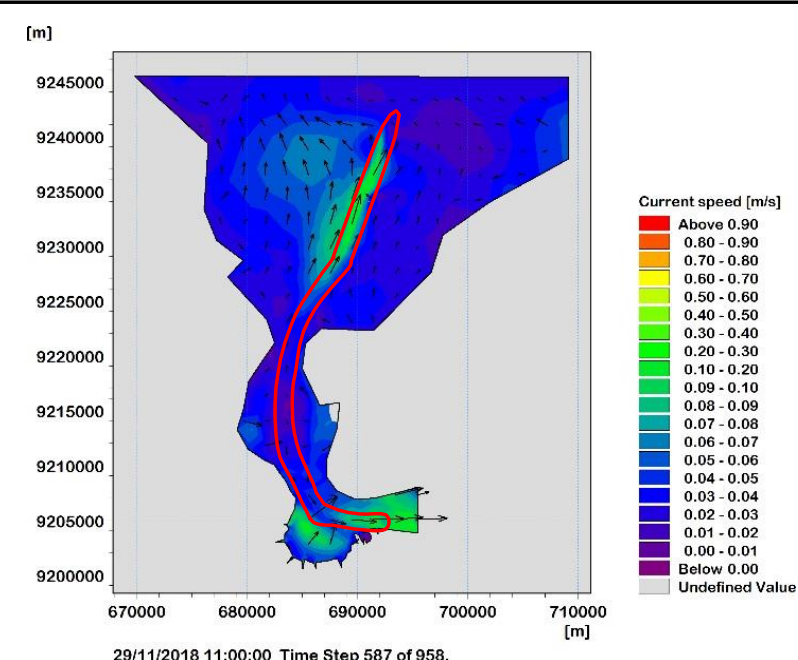

(d)

Gambar 11. Pola Arus Post-Survey Kondisi 2

\section{Pemodelan Sedimen}
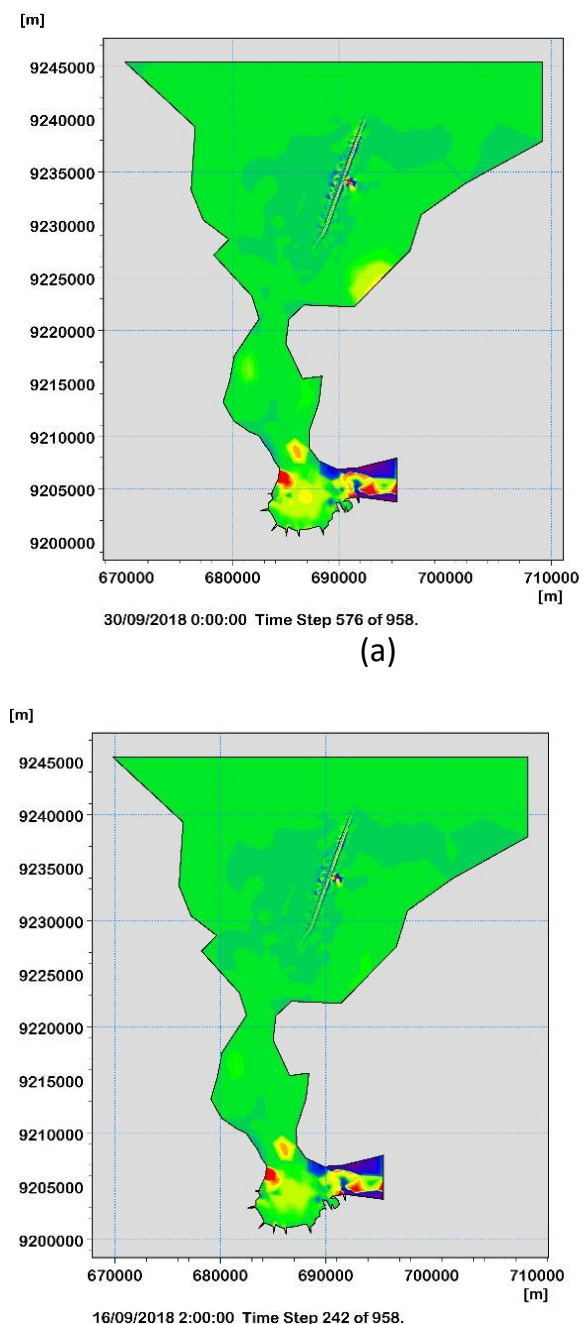

(b) (a)
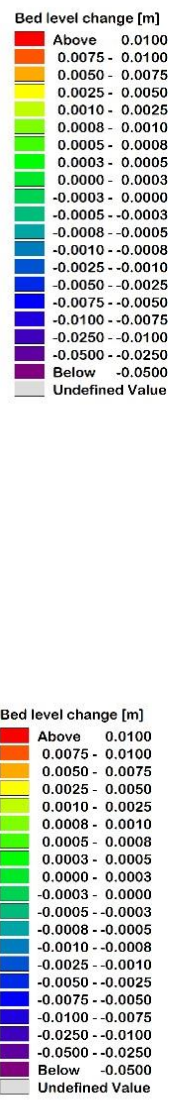

16/09/2018 2:00:00 Times

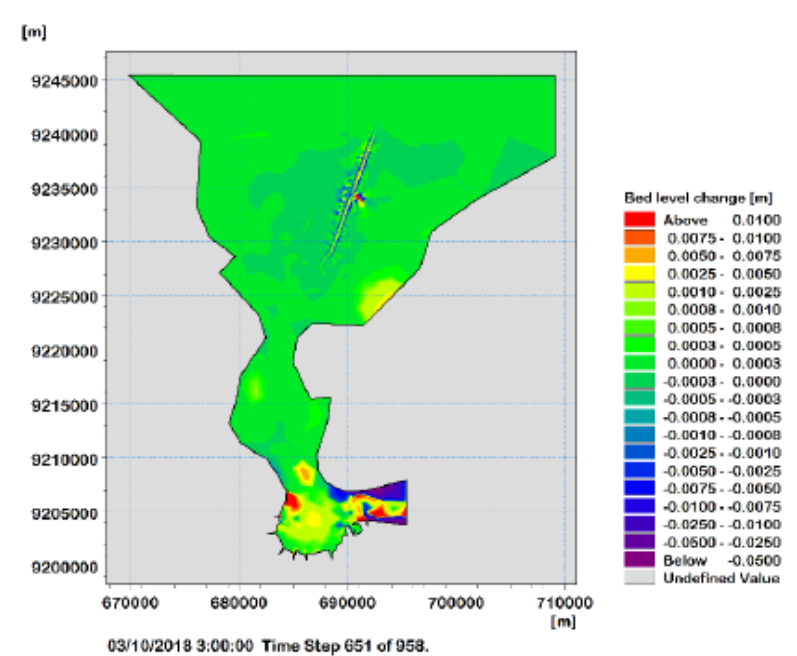

(c)

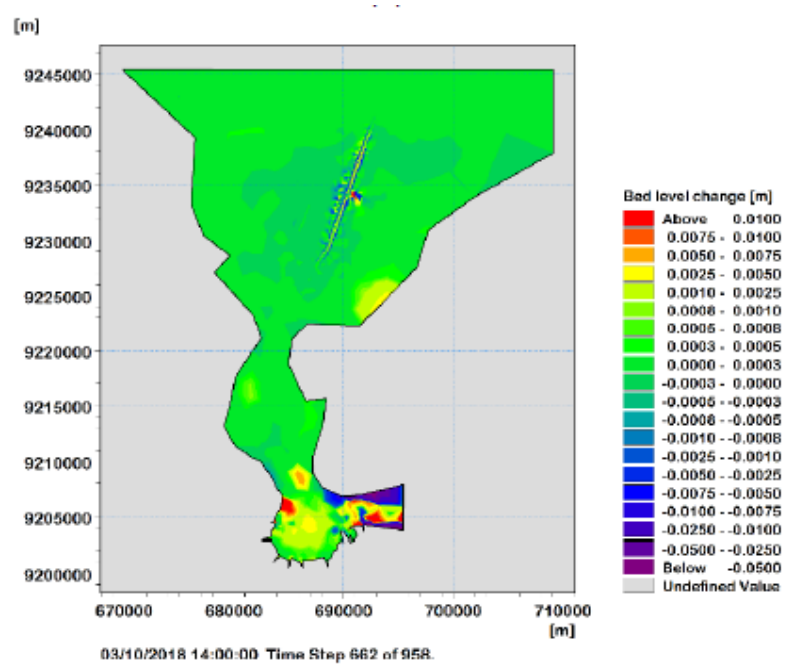

(d)

Gambar 12. Perubahan Dasar Laut Pre-Survey

Pemodelan sedimen dilakukan selama 40 hari dengan kondisi yang sama seperti pemodelan arus. Analisa model sedimen dilihat melalui perubahan dasar laut selama (a)pasang purnama, (b)surut purnama, (c)pasang perbani dan (d)surut perbani yang akan ditunjukan pada Gambar 1214.

Gambar 12 menunjukan perubahan dasar laut yang terjadi pada kondisi Pre-Survey. Secara keseluruhan, terlihat hasil pemodelan menunjukan besar perubahan dasar laut akibat pergerakan sedimen memiliki nilai penurunan hingga lebih dari $-0,0500 \mathrm{~m}$ dan kenaikan hingga lebih dari 0,01 m. Walaupun pada hasil terlihat dominan nilai penurunan dan kenaikan secara urut adalah $-0,0003 \mathrm{~m}$ dan 0,0003 m. Namun dapat dilihat juga kenaikan dan penurunan tersebut terjadi di area Alur Pelayaran dan area yang dekat dengan Pelabuhan Tanjung Perak. Hal 
ini diakibatkan karena pada pemodelan arus yang dihasilkan pada sub bab sebelumya terjadi arus yang cukup besar di daerah dekat area Alur Pelayaran dan sekitar area Pelabuhan Tanjung Perak.

Gambar 13 menunjukan perubahan dasar laut yang terjadi pada Post-Survey kondisi 1. Secara keseluruhan, terlihat pada hasil pemodelan menunjukan besar perubahan dasar laut akibat pergerakan sedimen memiliki nilai penurunan dan kenaikan yang lebih besar dan terjadi pada beberapa area hingga diatas 0,01 meter. Hal ini diakibatkan oleh hasil pemodelan arus yang terjadi dengan adanya perputaran arus yang mengakibatkan area area tersebut mengalami kenaikan yang cukup besar. Untuk wilayah Alur Pelayaran yang memiliki sediment trap dan area sekitar Pelabuhan Tanjung Perak yang juga memiliki kenaikan dan penurunan dasar laut yang diakibatkan oleh keluar masuknya arus pada area pemodelan yang terjadi pada hasil pemodelan lainnya.
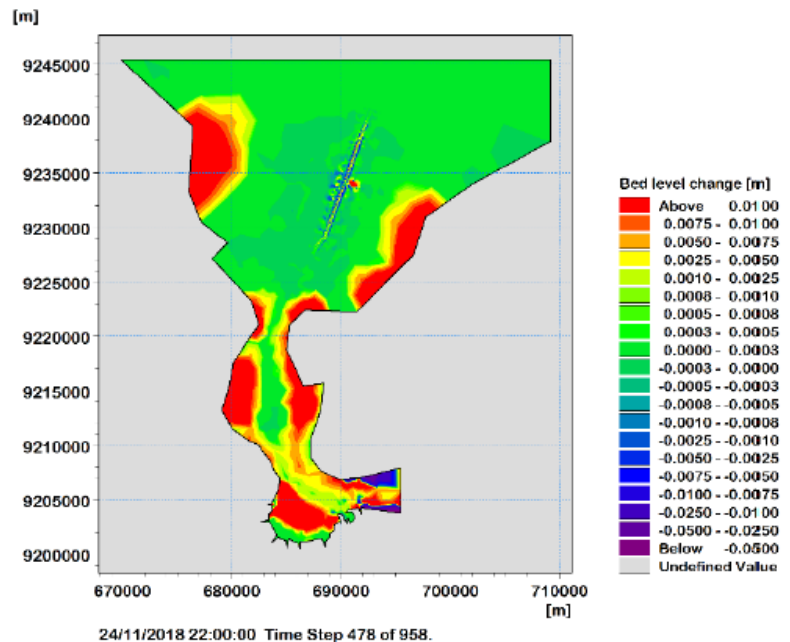

(a)

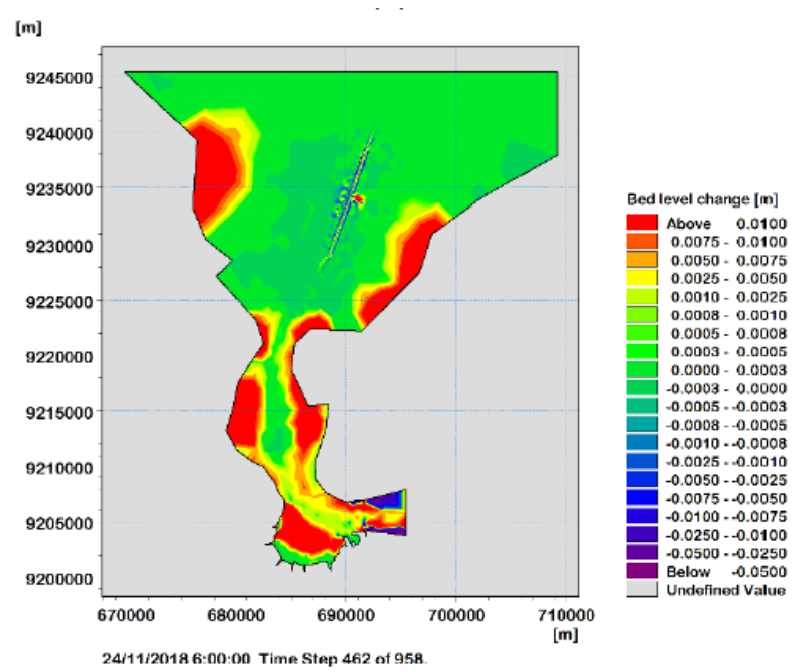

(b)

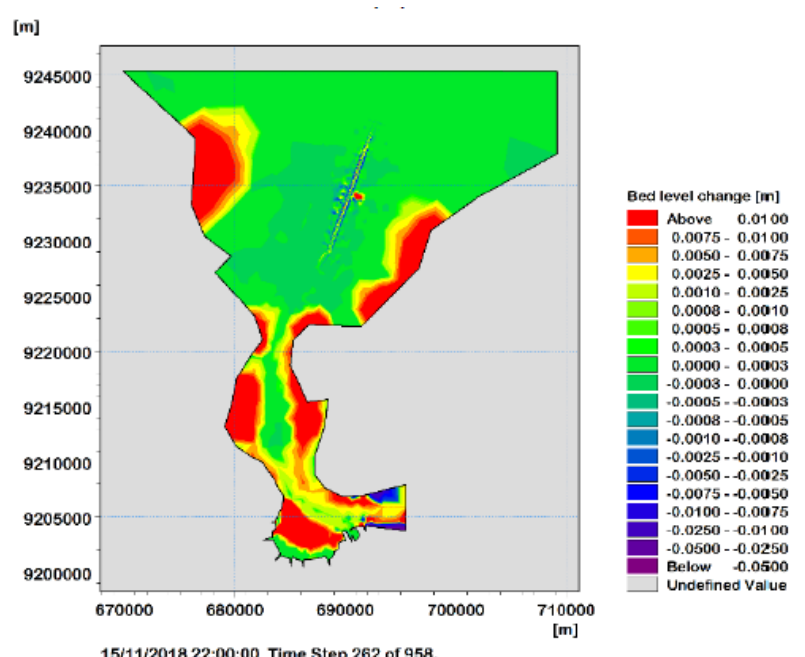

(c)

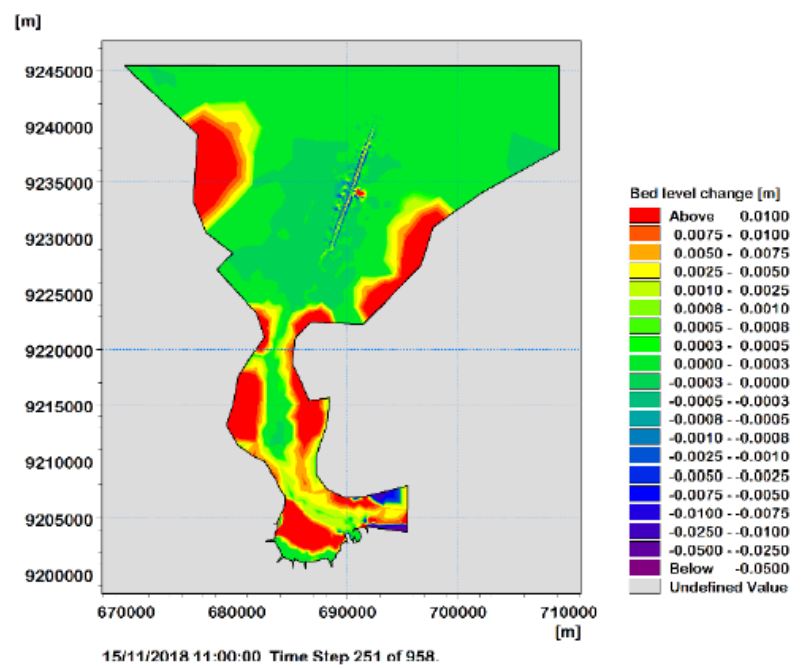

(d)

Gambar 13. Perubahan Dasar Laut Post-Survey Kondisi 1

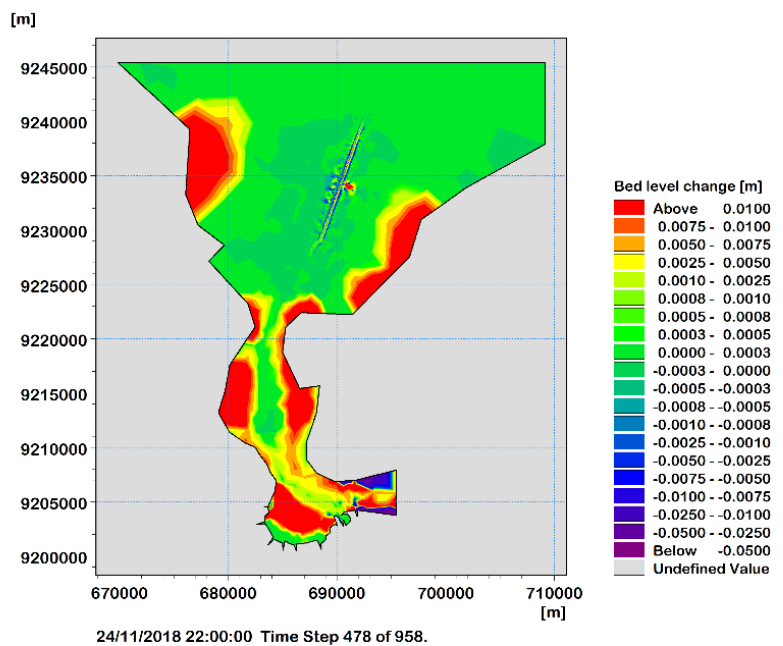

(a) 


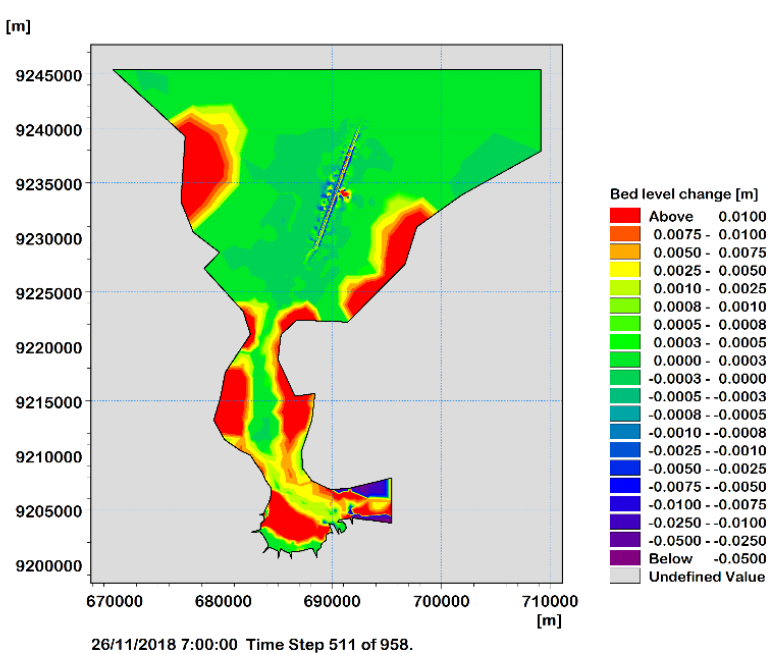

(b)

[m]

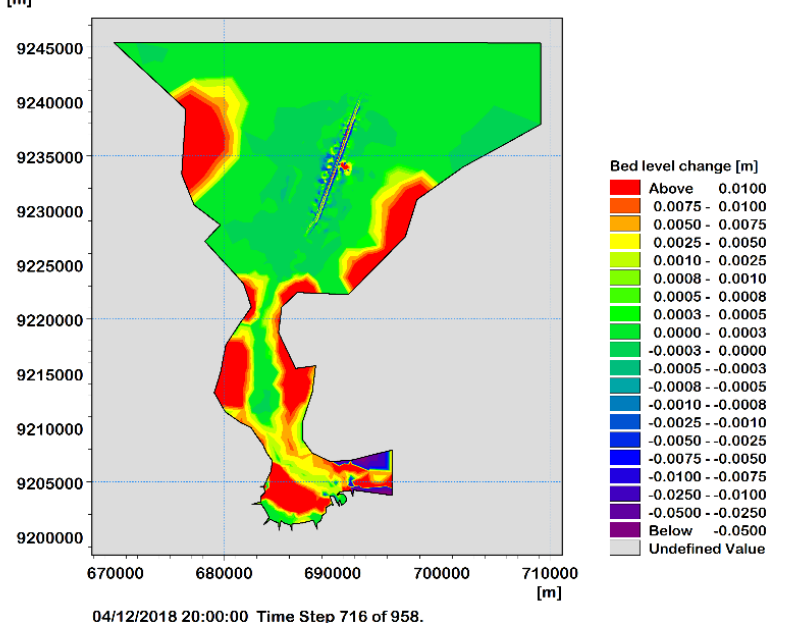

(c)

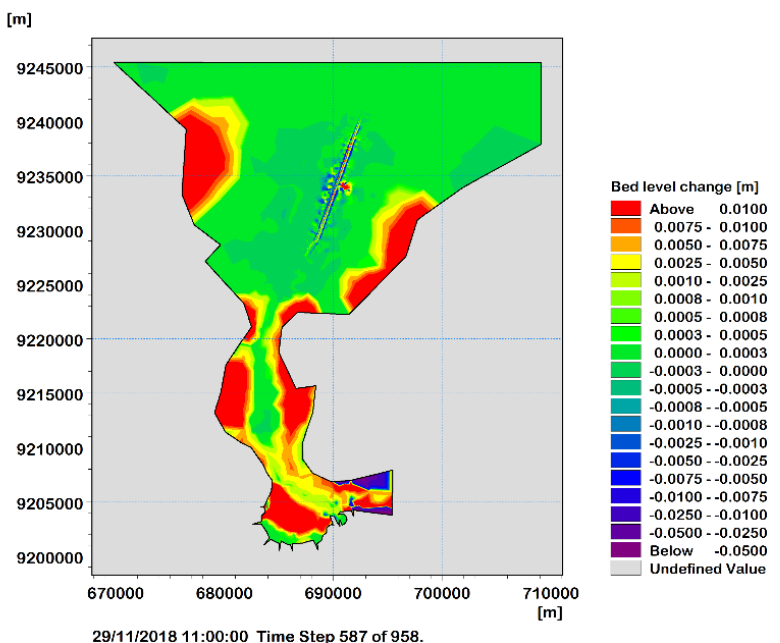

(d)

Gambar 14. Perubahan Dasar Laut Post-Survey Kondisi 2

Pada Gambar 14 menunjukan perubahan dasar laut yang terjadi pada Post-Survey Kondisi 2. Secara keseluruhan, hasil pemodelan dominan menunjukan besar perubahan dasar laut akibat pergerakan sedimen memiliki hasil yang tidak jauh berbeda dengan hasil Post-Survey Kondisi 1. Hal ini diakibatkan perbedaan antara Post-Survey kondisi 1 dan kondisi 2 hanya pada penggunaan dari sediment trap pada Alur Pelayaran di wilayah utara.

\section{Dampak Sedimentasi Terhadap Alur}

Dari perbedaan yang dimiliki oleh Post-Survey kondisi 1 dan kondisi 2, dilakukan analisa perbandingan antara kedua kondisi tersebut. Gambar 15 akan menunjukan perbedaan yang terjadi antara kedua kondisi dilihat dari (a)timestep 120 (awal), (b)timestep 540 (tengah), dan (c)timestep 958 (akhir).
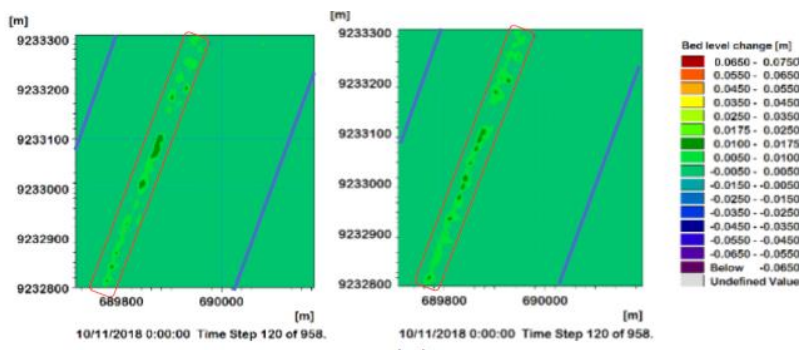

(a)
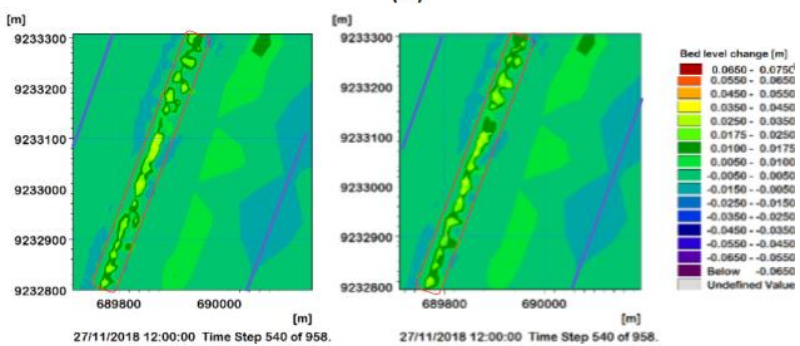

(b)
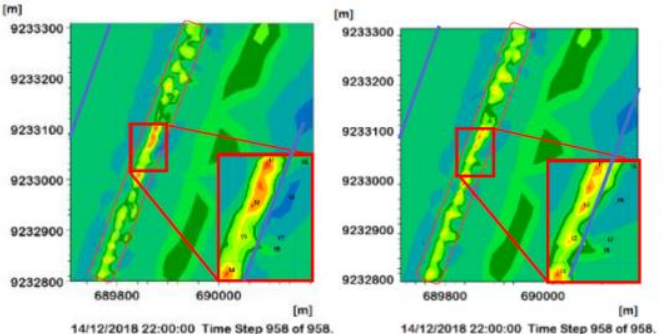

(c)

Gambar 15. Perbandingan Perubahan Dasar Laut Awal, Tengah dan Akhir Pemodelan

Terlihat pada Gambar 15, garis biru merupakan batas alur pelayaran sedangkan garis merah adalah area sediment trap. Perubahan yang terjadi dimulai dari timestep 120 belum terlihat perbedaan pada kondisi 1 dan 2. Pada timestep 540 terlihat kondisi 2 mulai memiliki area penambahan yang lebih tersebar. Hingga timestep 958 semakin terlihat daerah kondisi 2 memiliki 
daerah yang lebih besar. Walaupun hasil yang didapatkan pada kondisi 1 ada area yang mengalami penambahan hingga 0,072 meter dan kondisi 2 hanya 0,062 meter. Hal tersebut hanya terjadi di beberapa titik pada kondisi 1 , dan kondisi 2 yang memang terlihat lebih tersebar area penambahannya.

\section{KESIMPULAN}

Kesimpulan yang didapatkan dari penelitian ini adalah:

a. Dari hasil pemodelan didapatkan bahwa secara keseluruhan pada Pre-Survey memiliki nilai yang dominan di penurunan maupun kenaikan dasar laut akibat pergerakan sedimen yaitu dengan nilai penurunan sebesar $-0,0003 \mathrm{~m}$ dan kenaikan 0,0003 $\mathrm{m}$ walaupun ada kenaikan dan penurunan maksimal hanya pada area sekitar Pelabuhan Tanjung Perak, untuk Post-Survey kondisi 1 dan 2 secara keseluruhan pun memiliki hasil pemodelan yang dominan terlihat sama yaitu penurunan dasar laut senilai 0,0003 $\mathrm{m}$ dan kenaikan $0,0005 \mathrm{~m}$ serta terjadinya kenaikan di beberapa area dengan nilai maksimal diakibatkan arus yang mengarah dan berputar di area tersebut.

b. Untuk melihat keefektifan sediment trap dapat dilihat dari adanya perbedaan antara Post-Survey kondisi 1 dan kondisi

2 dimulai dari awal pemodelan hingga akhir pemodelan. Pada area alur pelayaran memiliki nilai yang dominan hampir sama dimulai dari $-0,005$ meter hingga 0,0175 meter. Nilai penambahan maksimal yang dimiliki oleh kondisi 1 senilai 0,072 meter sedangkan pada kondisi 2 senilai 0,062 meter pada area sediment trap. Walaupun kondisi 1 memiliki nilai maksimal yang lebih besar dari kondisi 2, hal tersebut hanya terjadi di beberapa titik saja, dan dikarenakan pada kondisi 1 memiliki sediment trap sehingga kenaikan dasar laut lebih terpusat ke beberapa titik dan tidak tersebar seperti yang terjadi pada kondisi 2.

Adapun saran yang dapat diberikan untuk penelitian selanjutnya pada bidang terkait adalah: a. Penambahan parameter-parameter pemodelan seperti suhu, tekanan, dan salinitas (baroklinik) sebagai parameter masukan model, agar pemodelan bisa lebih mendekati kondisi lapangan.

b. Pembuatan mesh yang lebih rapat sehingga hasil pemodelan dapat lebih teliti.

c. Memperpanjang waktu simulasi pemodelan, sehingga dapat dilakukan monitoring pada jangka waktu yang lama.

\section{UCAPAN TERIMA KASIH}

Penulis M.R.F.A mengucapkan terima kasih kepada dosen pembimbing, Bapak Danar Guruh Pratomo, S.T., M.T., Ph.D atas kesediaannya untuk membimbing dalam penelitian ini. Selain itu penulis mengucapkan terima kasih kepada PT. Alur Pelayaran Barat Surabaya (PT. APBS), Badan Informasi Geospasial (BIG), dan European Centre for Medium-Range Weather Forecasts (ECMWF) yang telah memberikan data untuk melakukan penelitian ini.

\section{DAFTAR PUSTAKA}

Anonim. (2019). Pelabuhan Tanjung Perak Surabaya. Retrieved from https://www.eastjava.com/ tourism/surabaya/ina/tanjung-perak.html

Chai, T., \& Draxler, R. R. (2014). Root mean square error ( RMSE) or mean absolute error ( MAE)? Arguments against avoiding RMSE in the literature, (2005), 1247-1250. https://doi.org/ 10.5194/gmd-7-1247-2014

Chen, C., Beardsley, R. C., \& Cowles, G. (2006). An Unstructured-Grid, Finite-Volume Coastal Ocean Model (FVCOM) System, 19(1), 78-89.

IDEQ Storm Water Best Management Practices Catalog. (2005). Sedimentation Trap (Basin) Description.

Kementrian Perhubungan Republik Indonesia. Keputusan Menteri Perhubungan Republik Indonesia (2016).

Khotimah, M. K. (2012). Validasi Tinggi Gelombang Signifikan Model Gelombang Windwave-5 dengan Menggunakan Hasil Pengamatan Satelit Altimetri Multimisi. Universitas Indonesia.

Kramadibrata, S. (2002). Perencanaan Pelabuhan. Bandung: ITB.

Kurniawan, A., \& Pradana, R. A. (2016). Pemodelan Aliran Material Sedimen Akibat Arus Pasang Surut Untuk Pemeliharaan Kedalaman Perairan Pelabuhan (Studi Kasus: Pelabuhan Tanjung Perak-Teluk Lamong, Surabaya). Geoid, 12(1), 
60-67.

Medium Corporation. (2016). MAE and RMSE - Which Metric is Better? Mean Absolute Error versus Root Mean Squared Error. Retrieved from https://medium.com/human-in-a-machineworld/mae-and-rmse-which-metric-is-bettere60ac3bde13d

Triatmodjo, B. (1999). Teknik Pantai. Yogyakarta: Beta Offset Yogyakarta.
Triatmodjo, B. (2010). Perencanaan Pelabuhan. Yogyakarta: Beta Offset Yogyakarta.

Wirosoedarmo, R., Haji, A. T. S., \& Kristanti, E. D. (2008).

Perilaku Sedimentasi dan Pengaruhnya Terhadap Kinerja Saluran pada Jaringan Irigasi Waru-Turi Kanan Kediri. Jurnal Teknologi Pertanian Vol. 12 No.1 (April 211) 68-75, 12(1), 68-75. 